\title{
New explosive eruption at Ubinas volcano (Peru)
}

\section{Bulletin of Volcanology Editor-in-Chief ${ }^{1}$}

Published online: 13 August 2019

(C) International Association of Volcanology \& Chemistry of the Earth's Interior 2019

A new eruption began at Peru's Ubinas volcano on 24 June 2019. The Instituto Geofísico del Perú (IGP) reported that webcams recorded ash, gas, and steam plumes rising from the crater. The plumes were visible in satellite images rising to $6.1 \mathrm{~km}(20,000 \mathrm{ft})$ a.s.l. and drifting N, NE, and E. The Smithsonian Institution's Global Volcanism Program lists Ubinas as Peru's most active volcano. It has had 10 eruptions since 1900 with the last being reported in November 2016 (https:// volcano.si.edu/volcano.cfm?vn=354020).

In response to this new activity, the Bulletin of Volcanology has opened up access to two classic scientific papers that provide better understanding of Ubinas, its past activity, and the hazard posed by the volcano. The first paper, by de Silva and Francis (1990), used high spatial resolution satellite data and space shuttle photographs to identify, describe, and catalog the remote volcanoes of southern Peru. De Silva and Francis described the volcano as "a broad, quasi-symmetrical cone" with a "truncated appearance due to a large summit crater" and commented that "the presence of deep canyons on the southeastern side of the volcano presents considerable hazard to the many small settlements there."

Thouret and co-workers (2005) followed up by defining the type of activity experienced by, and the eruptive history of Ubinas. Among the most recent activity, Thouret et al. identified a major collapse that fed a debris avalanche 3600 years ago, "countless" explosive events over the last 9700 years, and a Plinian eruption, dated at A.D. 1000-1160, that "produced an andesitic pumice-fall deposit, which achieved a thickness of $25 \mathrm{~cm} 40 \mathrm{~km}$ SE of the summit." Like Silva and Francis, Thouret et al. concluded that:

Recent eruptions indicate that Ubinas poses a severe threat to at least 5,000 people living in the valley of the Rio Ubinas, and within a $15-\mathrm{km}$ radius of the summit. The threat includes thick tephra falls, phreatomagmatic ejecta, failure of the unstable south flank with subsequent debris avalanches, raintriggered lahars, and pyroclastic flows.

The Bulletin of Volcanology was founded in 1922 and is the official journal of the International Association of Volcanology and Chemistry of the Earth's Interior (IAVCEI).The Bulletin of Volcanology publishes papers on volcanoes, their products, their eruptive behavior, and hazards (https://link.springer.com/journal/445). The press release initiative is a collaboration between the Bulletin of Volcanology, the Smithsonian Institution's Global Volcanism Program, and the Smithsonian/USGS Weekly Volcanic Activity Report. Open access to the papers released here can be found at:

Link: https://link.springer.com/article/10.1007/ BF00304100

Link: https://link.springer.com/article/10.1007/s00445004-0396-0

Bulletin of Volcanology Editor-in-Chief

andrew.harris@uca.fr; gvp@si.edu

1 Bulletin of Volcanology Editorial Office, Laboratoire Magmas et Volcans, Université Clermont Auvergne, Aubière, France 